\title{
Analysis of Similarities Between Five Indigenous Bio-Catalyst Extracts used by Several Communities in Kenya
}

\author{
Bakari Chaka, \\ Osano Aloys,
}

Department of Mathematics and Physical sciences, School of Science and Information sciences, Maasai Mara University, Narok, Kenya

\section{Magu Martin,}

Department of Chemistry, Faculty of Science and Technology, Multimedia University of Kenya, Nairobi, Kenya

\begin{abstract}
Commercial fermentation additives are quite expensive leading to increased production costs. Several communities in Kenya have continuously enjoyed fast saccharification of biomass during cooking and fermentation of porridge and ethanol using bio-catalysts. Infusion of these bio-catalysts into modern-day science is crucial in optimization of yields and reduction of production costs in food, alcohol, pharmaceuticals and energy industries. This study aimed at characterizing five extracts (Terminalia b., Acanthaceae spp., Osyris lanceolata, Santaraseae spp. and Kigelia africana) for possible similarities in physical-chemical parameters, elemental composition and ionic stability. Water extracts were preferred as natively done by these communities. Wet chemistry was used for physical-chemistry parameters and elemental composition while spectroscopy was used to analyze presence of bio-metals, functional groups, conjugation and ligands present. Lab simulation studies were conducted to evaluate ionic stabilities. The results indicated the samples had similar $\mathrm{pH}$, conductivity and volatile solids with slight variations in alkalinity and fatty acids. There were similarities in the functional group peaks and conjugation patterns. The ions of $\mathrm{Cu}(\mathrm{OH})_{2}, \mathrm{Fe}(\mathrm{OH})^{2+}, \mathrm{ZnOH}^{+}, \mathrm{Cr}(\mathrm{OH})^{2+}$ and $\mathrm{Co}^{2+}$ were found to be dominant in all biocatalyst extracts. Terminalia $b$. and Osyris lanceolata were found to have relatively higher sulfate, phosphate levels while nitrate levels were similar in all the samples except for Terminalia $b$. biocatalysts. These compounds extracted from these herbs can be commercialized for industrial fermentation processes.
\end{abstract}

Keywords: Indigenous Bio-Catalysts, Similarities, Fermentation 


\section{Introduction}

One of the most vital bio-chemical reactions is respiration. Anaerobic respiration majorly occur as fermentation of biomass. Fermentation is the precursor reaction to several significant industrial and domestic reactions. Fermentation is applied in manufacture of food, beverages, pharmaceuticals, chemicals and reagents, alcohol as well as in energy industry (Mandenius and Gustavsson, 2015). Home-baking and preparation of porridge also require fermentation. Fermentation process is spontaneous under anaerobic environment (Minarrieta et al. 2017). Unfortunately, fermentation process is very slow and more energy and/or catalysts have to be used for feasible industrial and domestic reactions. While energy demand is on the rise due to increased human needs, bio-chemical reaction catalysts are rare and expensive (Panagiotopoulou et al. 2014).

Saccharification of biomass is a key step in fermentation (Sridevi et al. 2015). Actually, most of the energy and time is used in saccharification due to the nature of bonds involved. Strong glycosidic bonds found in ligno-cellulose and amide bonds found in proteins require stronger forces to break down (Yuki et al. 2008. A lot of energy is thus used to heat reactors for optimal biomass hydrolysis and to increase regioselectivity of reactions. On the other hand, a bulging human population and increased needs associated with this increment dictates for the need for more energy sources and optimization of the current ones. Optimization of renewable energy sources for more production and safer combustion of carbon-based fuels should thus be emphasized. While both options are feasible even at industrial scales, the former is greener and more appealing.

The success of waste-to-energy processes is questionable in regards to the efforts and time consumed (Li et al., 2014; Don et al., 2012). Biofuel conversion from ligno-cellulosic biomass rates are still annoyingly low (Lillebo et al. 2013). Natural conversion pathways are not only slow but also lack regioselectivity which introduce more costs for separation of the products (Behenna et al. 2011). Use of catalysts to hasten biomass hydrolysis using less energy and increase product specificity is thus pertinent. Many catalysts have been employed in hydrolysis of biomass to fermentation products (Kalyani et al. 2017). It is however unfortunate that most of these catalysts are expensive, require specific conditions and are tailored for specific reactions only (Wright, \& Solar Energy Research Institute, Golden, CO (US), 1988).

Chemical catalysts used in fermentation of biomass involve acids such as formic acid (Marzialetti, 2011) and salts of transition metal origin (Ouyang et al. 2012). Ferric and cobalt salts have been successfully used for fast hydrolysis of ligno-cellulose to furfuric acid (Sparks, 2015); a major precursor in this degradation pathways. These chemicals are expensive at industrial scales. On the other hand, biological catalysts used include fungi such as yeast 
as well as genetically engineered enzymes (Bychkov et al. 2016). The natural anaerobic archea involving acidogenic, acetic and methanogenic bacteria in a natural biomass setup do not always suffice for fast biomass degradation pathways. Synthetic archea, enzymes and fungi all require very specific substrate and conditions to culture in large scale (Stockmann et al. 2014). Preparation of these catalysts have thus been left to only a few companies worldwide (Lin et al. 2014) accruing monopolistic disadvantages to these catalysts. There is thus need for a cheaper and sustainable means to generate and propagate bio-chemical catalysts.

Several communities in Kenya used indigenous salts to hasten saccharification of cellulose during food preparation (Osano et al. 2015). Other communities also used plant extracts to hasten saccharification and fermentation of biomass during porridge fermentation and preparation of alcohol used for traditional events. While use of these extracts have been outdated by modern-day chemicals and enzymes in industries and homes, their use has silently but successfully continued in the so called 'backward communities.' Not only are they cheap but they also enjoy a lot of atom economy with very little by-products formed.

This study purposed to characterize five plant extracts anciently used for saccharification and fermentation of biomass for possible similarities. Santaraseae spp. and Osyris lanceolata leaves and bark extracts were used by the Aembu community to hasten porridge preparation and fermentation of milk (sour milk is a communal delicacy). Terminalia brownii leave extracts were used by the Aandia community of western slopes of Mt. Kenya to hasten ethanol fermentation. Kigelia Africana (sausage tree) has continuously been used by many central Kenya natives to prepare traditional alcohol known as 'muratina.' Acanthaceae spp. bark extracts are used by the Maasai community of Kenya to prepare traditional alcohol. Water extracts were preferred, as anciently done by the communities for actualization of findings. Evaluation of similar elements, ionic state, structure or morphology would go a long way in opening doors for propagation of the bio-catalysts or optimize on extraction of 'the common compounds.'

\section{Materials and Methods \\ Design of Experiment}

Five indigenous bio-catalysts were separately characterized for possible similarities in composition and morphology. An independent measures experimental design was followed with all samples being subjected to similar experimental treatments. Solvent extraction was done using water as natively done in the traditional setups of these bio-catalysts. $5 \% \mathrm{w} / \mathrm{v}$ concentrations were used. Physical-chemical parameters including $\mathrm{pH}$, electrical conductivity, total and volatile solids as well as anaerobic digestion 
parameters such as dissolved oxygen, volatile fatty acids and alkalinity were measured. Five bio-metals (copper, chromium, cobalt, zinc and iron) composition were analyzed using atomic absorption spectroscopy and ionic speciation by PHREEQC simulation software. Functional group analysis and conjugation were done using FTIR and UV VIS spectroscopy respectively. Phosphates, nitrates and sulfates were also analyzed by UV spectroscopy.

\section{Materials}

\section{Chemicals}

All chemicals used were lab grade unless otherwise stated. The chemicals used were obtained from Sigma-Aldrich.

Sodium hydroxide pellets, potassium hydroxide pellets, nitric acid, sulfuric acid, hydrochloric acid, absolute ethanol, methyl red indicator, Analytical grade reagents; sodium chloride, glycerol, ammonium metavanadate, hydrazine sulphate, salicyclic acid, potassium bromide and ascorbic acid.

\section{Equipment}

Access to Shimadzu Fourier Transform Infrared (FTIR), Shimadzu1800 ultraviolet visible spectrophotometer (UV-VIS), Atomic absorption spectrophotometer (PG-990 AAS), Hanna G-114 pH meter.

\section{Methods}

\section{Sample extraction}

Terminalia $b$. and Santaraseae spp. fresh leaves were squeezed and $5 \mathrm{ml}$ of the resulting crude extracts soaked in distilled water to make $100 \mathrm{ml}$ solution. The solution was left to macerate completely for 24 hours at room temperature away from direct light. The mixture was then serially filtered using Whatman no. 42 filter papers and the resulting solution preserved. For Osyris lanceolata and Acanthaceae spp., the barks of these samples were ground to fine powder. $5 \mathrm{~g}$ of these powders were soaked in $100 \mathrm{ml}$ distilled water and the procedure done for Terminalia $b$. and Santaraseae spp. repeated. For Kigelia africana, wet tubers were air dried away from direct light at room temperature before crushing the fibers to obtain fine powder. The procedures used for Osyris lanceolate and Acanthaceae spp. were then followed. About a liter of each of the sample solutions were made for all the tests done.

\section{Sample characterization}

\section{pH, conductivity and dissolved oxygen}

$\mathrm{pH}$, electrical conductivity and dissolved oxygen were measured using a $\mathrm{pH}$ meter, conductivity meter and oxygen meter respectively.

\section{Total solids and volatile solids content}


$100.0 \mathrm{ml}$ of sample solution was weighed, $\mathrm{M}_{1}$ and placed in an oven conditioned at $105^{\circ} \mathrm{C}$ for 6 hours before removing, cooling (in a desiccator) and reweighing. The new mass was recorded as $\mathrm{M}_{2}$.

$\%$ TS $=\frac{\mathrm{M} 2}{\mathrm{M} 1} \times 100 \%$

$100.0 \mathrm{ml}$ of another sample solution was also weighed, $\mathrm{M}_{1}$ and placed in an oven conditioned at $540^{\circ} \mathrm{C}$ for 1 hour before removing, cooling and reweighing. The new mass was recorded as $\mathrm{M}_{2}$.

$\% V S=\frac{\mathrm{M} 2}{\mathrm{M} 1} \times 100 \%$

\section{Sample alkalinity}

A raw sample was distilled in water (1:1) and the distillate titrated against standard $0.05 \mathrm{~N} \mathrm{H}_{2} \mathrm{SO}_{4}$ solution up to $\mathrm{pH} 4.0$. The volume of sample solution used was used to determine the concentration of Alkalinity in the sample.

\section{Sample volatile acids}

A raw sample was distilled in water (1:1) and the distillate titrated against standard $0.1 \mathrm{~N} \mathrm{NaOH}$ solution up to $\mathrm{pH} 8.3$. The volume of sample solution used was used to determine the concentration of VFAs in the sample.

\section{Total dissolved solids and total suspended solids}

For these procedures, sample concoction that had not been serially filtered were used. For the total suspended solids, the mass of $100.0 \mathrm{ml}$ extract solution was weighed. The solution was then passed through a pre-weighed Whatman \#41 filter paper. The used filter paper was then dried in an oven at $105^{\circ} \mathrm{C}$ for 1 hour, cooled in a desiccator before reweighing the filter paper and solution again. The difference in weight of the filter paper is the Total Suspended Solids (TSS).

Total dissolved solids were obtained by subtracting total suspended solids from the total solids values.

\section{IR Functional Groups}

The extracts were heated slowly at $60^{\circ} \mathrm{C}$ until all the water was dried. The samples were then cast into pellets using $\mathrm{KBr}$ pellet before analyzing for functional groups using IR Spectrometer.

\section{Conjugation Analysis}

Extracts were diluted serially using distilled water until a clear spectrum could be seen on the UV VIS monitor. A scan was then run between $190-900 \mathrm{~nm}$ wavelength. 


\section{Bio-metal analysis}

Extracts obtained were triple filtered using Whatman \# 42 filter papers before analyzing for $\mathrm{Zn}, \mathrm{Cu}, \mathrm{Co}, \mathrm{Fe}$ and $\mathrm{Cr}$ using Flame Atomic Absorption Spectrometer (AAS).

The conditions for the AAS are as summarized in table 1 below;

Table 1: AAS conditions used to analyze the bio-metals

\begin{tabular}{cccccc}
\hline Bio-metal & Wavelength & Bandwidth & $\begin{array}{c}\text { Lamp } \\
\text { current }\end{array}$ & Flame & Sensitivity \\
\hline $\mathrm{Cr}$ & $357.9 \mathrm{~nm}$ & $0.4 \mathrm{~nm}$ & $5.0 \mathrm{ma}$ & Air/Acetylene & $0.05 \mathrm{mg} / \mathrm{L}$ \\
$\mathrm{Co}$ & $240.7 \mathrm{~nm}$ & $0.4 \mathrm{~nm}$ & $5.0 \mathrm{ma}$ & Air/Acetylene & $0.05 \mathrm{mg} / \mathrm{L}$ \\
$\mathrm{Cu}$ & $324.7 \mathrm{~nm}$ & $0.4 \mathrm{~nm}$ & $5.0 \mathrm{ma}$ & Air/Acetylene & $0.03 \mathrm{mg} / \mathrm{L}$ \\
$\mathrm{Fe}$ & $248.3 \mathrm{~nm}$ & $0.2 \mathrm{~nm}$ & $5.0 \mathrm{ma}$ & Air/Acetylene & $0.05 \mathrm{mg} / \mathrm{L}$ \\
$\mathrm{Zn}$ & $213.9 \mathrm{~nm}$ & $0.4 \mathrm{~nm}$ & $4.0 \mathrm{ma}$ & Air/Acetylene & $0.01 \mathrm{mg} / \mathrm{L}$ \\
\hline
\end{tabular}

Bio-metal speciation was done by combining the concentrations of the biometals with their electrical conductivity, $\mathrm{pH}$ and temperature of solution. These simulations were done with the help of PHREEQC software.

\section{Ligands analysis}

Nitrates

Nitrate standards were prepared by dissolving $8.0 \mathrm{~g}$ of salicyclic acid in $100 \mathrm{ml}$ of $1 \mathrm{M} \mathrm{H}_{2} \mathrm{SO}_{4}$ acid then swirling to fully dissolve. $10 \mathrm{ml}$ of this solution was added to $90 \mathrm{ml}$ of aliquot sample solution. Acidification using $1 \mathrm{M}$ $\mathrm{HCl}$ was done to minimize interference by other ligands. Absorbance was checked in the range of $520-560 \mathrm{~nm}$.

\section{Sulfates}

For standard preparation, $10 \mathrm{~g}$ of $\mathrm{NaCl}$ and $10 \mathrm{ml}$ of conc $\mathrm{HCl}$ acid were added to $40 \mathrm{ml}$ of glycerol solution. A yellowish color was formed. $5 \mathrm{ml}$ of this solution was added to $45 \mathrm{ml}$ of analyte solution and the absorbance read at 410 $430 \mathrm{~nm}$.

\section{Phosphates}

A conditioning reagent was added. It was made by dissolving $1.7081 \mathrm{~g}$ of ammonium metavanadate and ascorbic acid $(5.82 \mathrm{~g} / 300 \mathrm{ml}$ distilled water) in $150 \mathrm{ml}$ warm water. The solution was cooled before diluting to $250 \mathrm{ml}$. Exactly $0.125 \mathrm{~g}$ of hydrazine sulphate in $100 \mathrm{ml}$ distilled water was added.

Analyte samples were diluted by a factor of 10 and added the conditioning reagent before measuring the absorbances at $420-450 \mathrm{~nm}$ against those of the blank and standards. 


\section{Data analysis}

Statistical tools used include mean and median to test the appearance of the data sets while standard deviation and variance monitored the spread of the data. Correlation and regression to check on relation between absorbance and concentration during AAS and UV VIS spectroscopy analysis were also done. f-test was used to check the significance in the variances while t-test was used to assess how the means of the data are related. Statistical packages used include Microsoft Excel, PHREEQC and OriginLab applications.

\section{Results and Discussions}

\section{Physical-chemical and bio-chemical analysis}

The $\mathrm{pH}$ of sample solutions is a function of several parameters, including the volatile acids present and composition of other metals and ligands (Schultz et al. 2015). The bio-catalysts $\mathrm{pH}$ ranged between $5.950 \pm 1.001$ (Osyris lanceolata) to $7.160 \pm 0.006$ (Acanthaceae spp.). In general, the samples were slightly acidic. Bio-catalyst $\mathrm{pH}$ is a key factor in determining the existence of crucial micro-organisms necessary for biomass saccharification and fermentation (Berthelot et al., 2019). Most hydrolytic enzymes thrive in acidic media (Amend and Shock, 2001) thus Osyris lanceolata specie could harbor the most population of these enzymes. Kaldor and Woodin, (1982); proposes that a good bio-catalyst should lie in the $\mathrm{pH}$ range of 6.0-7.0 to increase its availability and applicability. This $\mathrm{pH}$ range is quite neutral thus can easily accommodate both acidic and alkaline microorganisms. Chude-Okonkwo et al. (2017); reports that the stability of crucial polymer-protein complexes involved in bio-catalysis processes depend on $\mathrm{pH}$ and ionic strengths.

Ionic strengths of solutes in solutions were measured as electrical conductivities in this study. From the results, there was direct correlation between the electrical conductivity of the samples and their $\mathrm{pH}$. Acanthaceae spp. sample with the highest $\mathrm{pH}$ value had the highest conductivity value $(57.472 \pm 0.012 \mathrm{mS})$. Osyris lanceolata specie had the lowest $\mathrm{pH}$ and conductivity value $(5.950 \pm 1.001 \mathrm{mS})$. Several enzymatic reactions are hydrophobic in nature (Duijnhoven et al. 2015); thus making bio-catalyst samples with more electrical conductivity in a better position to allow for these reactions. Marriott et al. (2016); reports that presence of a polar medium supports existence of important enzymes fundamental in catalyzing biomass. The total solids and total dissolved solids content of solutions are also related to the electrical conductivity. The same order was witnessed in the biocatalysts analyzed.

The average values of the $\mathrm{pH}$, total solids (TS), volatile solids (VS), total suspended and dissolved solids (TSS and TDS), electrical conductivity (EC), 
dissolved oxygen (DO), volatile fatty acids (VFAs) and alkalinity (ALK) are analyzed and summarized in table 2 below.

Table 2: Characterization of indigenous biocatalyst extracts

\begin{tabular}{cccccc}
\hline Parameter & \multicolumn{5}{c}{ Samples } \\
\cline { 2 - 6 } & Terminalia b. & $\begin{array}{c}\text { Acanthaceae } \\
\text { spp. }\end{array}$ & $\begin{array}{c}\text { Santaraseae } \\
\text { spp. }\end{array}$ & $\begin{array}{c}\text { Osyris } \\
\text { lanceolata }\end{array}$ & Kigelia africana \\
\hline $\mathrm{pH}$ & $6.713 \pm 0.045$ & $7.160 \pm 0.006$ & $6.880 \pm 0.123$ & $5.950 \pm 1.001$ & $6.810 \pm 0.187$ \\
$\mathrm{EC}(\mathrm{mS})$ & $48.428 \pm 0.998$ & $57.472 \pm 0.012$ & $34.600 \pm 1.225$ & $31.200 \pm$ & $41.200 \pm 1.168$ \\
& & & & 2.436 & \\
$\mathrm{TS}(\mathrm{g} / \mathrm{L})$ & $9.000 \pm 0.000$ & $11.000 \pm 0.000$ & $11.000 \pm 0.000$ & $11.670 \pm 0.000$ & $10.667 \pm 0.000$ \\
$\mathrm{VS}(\mathrm{g} / \mathrm{L})$ & $7.333 \pm 0.000$ & $8.330 \pm 0.000$ & $7.000 \pm 0.000$ & $8.000 \pm 0.000$ & $3.000 \pm 0.000$ \\
$\mathrm{TSS}(\mathrm{g} / \mathrm{L})$ & $5.333 \pm 0.000$ & $2.667 \pm 0.000$ & $7.000 \pm 0.000$ & $6.670 \pm 0.000$ & $4.267 \pm 0.000$ \\
$\mathrm{TDS}(\mathrm{g} / \mathrm{L})$ & $3.670 \pm 0.000$ & $8.333 \pm 0.000$ & $4.000 \pm 0.000$ & $5.000 \pm 0.000$ & $6.400 \pm 0.000$ \\
DO (\%) & $10.467 \pm 0.306$ & $6.600 \pm 0.100$ & $10.400 \pm 1.010$ & $13.100 \pm 2.115$ & $8.800 \pm 0.986$ \\
VFA & $32.738 \pm 2.335$ & $28.389 \pm 1.386$ & $39.684 \pm 1.212$ & $32.738 \pm 1.111$ & $29.667 \pm 4.154$ \\
$(\mathrm{mg} / \mathrm{L})$ & & & & & \\
ALK & $7.200 \pm 0.000$ & $9.720 \pm 0.000$ & $6.100 \pm 0.000$ & $7.520 \pm 0.000$ & $9.160 \pm 0.000$ \\
$(\mathrm{mg} / \mathrm{L})$ & & & & & \\
\hline
\end{tabular}

From the data in figure 2 above, about $81 \%$ of the solid content in Terminalia $b$. were volatile while Acanthaceae spp., Santaraseae spp. and Osyris lanceolata all had more than $63 \%$ of their solids volatile. Only Kigelia africana had little volatile solids (28\%). Most of organic matter associated with biocatalytic activity are enzymes, some fungi strains and acids, all volatile in nature (Kinderlerer et al. 1989). Reduction in volatile solids imply high abundance in fixed solids. The biocatalytic nature of Kigelia africana might thus be induced by transition metals, also widely known as catalysts. Acanthaceae spp. and Kigelia africana species had more dissolved solids than the other samples. These findings are in tandem with their total solids, electrical conductivity and $\mathrm{pH}$ values. Kuzyakov and $\mathrm{Xu}$ (2013); reports that biocatalytic microorganisms prefer an ecological niche with more organic content with abundance or polymeric groups and protruded functional groups on their surface for enhanced activities (Yao et al. 2019). Such an environment is more profound in samples with more volatile solids and total suspended solids. The variation in volatile fatty acids was affected by the volatile and suspended solids. Therefore, Acanthaceae spp. and Kigelia africana had less volatile acids and more alkalinity. Alkalinity of biocatalysts represents the total buffer capacity of the samples against excessively acidic matter for optimal production of alkaline microorganisms (Soria et al. 2011). Alkalinity is crucial especially in biofuels (such as in biogas production). The alkalinity of biocatalysts should compose of soft ligands such as bicarbonates (Jakubowska and Normant-Saremba, 2015). Acanthaceae spp., Osyris 
lanceolata and Kigelia africana had more alkalinity levels thus more suitable in biogas production.

\section{Functional group of biocatalyst samples}

The FT-IR spectra of the bio-catalysts showed concise resemblance in positioning and intensity of most of the peaks. The collated FT-IR spectra of the biocatalysts are as illustrated in figure 1 below.

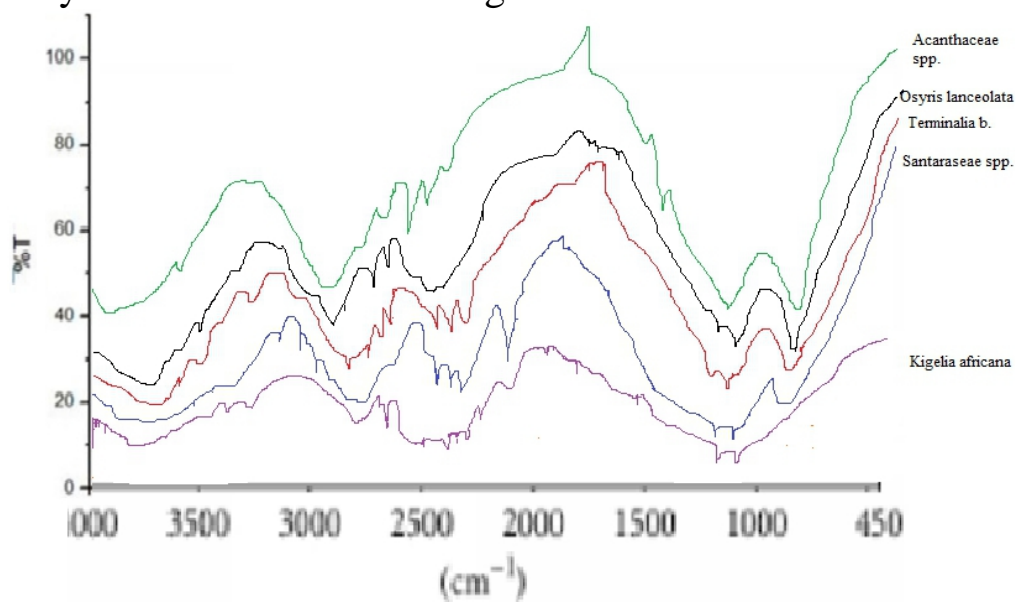

Figure 1; FT-IR spectra of the five biocatalysts analyzed

The pattern was more severe before $1200 \mathrm{~cm}^{-1}$ wavenumber. The peaks had a broad $\mathrm{O}-\mathrm{H}_{\mathrm{ROH}}$ peaks between $3100-3600 \mathrm{~cm}^{-1}$ indicating presence of alcohols. The FT-IR spectra of Aspergillus niger lipase enzyme (a biocatalyst) was found to exhibit dominant peaks at $3420-3150 \mathrm{~cm}^{-1}(-\mathrm{OH}$ stretching vibrations and $-\mathrm{NH}$ stretching vibrations) (Harvey, 2015). There were several vibrational $-\mathrm{CH}_{2}$ stretches at about $2850 \mathrm{~cm}^{-1}$ which were also observed in Nigel sativa biocatalytic extracts (Mihoubi et al. 2017). There were peaks at around $2250 \mathrm{~cm}^{-1}$ illustrating presence of amide groups and aryl compounds (Hasan et al. 2018). The lignin-based biocatalysts also had a sharp peak at around $1162 \mathrm{~cm}^{-1}$ which was also present in all the samples except the Acanthaceae spp. specie. There were two close peaks at around $1500 \mathrm{~cm}^{-1}$, possible due to trans alkenes and a further broad peak at $1050 \mathrm{~cm}^{-1}$ depicting presence of $\mathrm{C}-\mathrm{OH}$ peaks. Goacher et al. (2018); reported such peaks to be abundant in lignin biocatalysts analyzed. Several enzymes characterized were also found to have these peaks, especially $1080 \mathrm{~cm}^{-1}(\mathrm{C}-\mathrm{O}$ bond stretching vibrations) (Kristoffersen et al. 2019).

\section{Conjugation analysis of the bio-catalysts by UV VIS}

All samples were found to have a broad absorption peak with several multiplicities for Terminalia b., Osyris lanceolata and Santaraseae spp. 
samples. The peaks were found to range between 300 to $600 \mathrm{~nm}$. The UV VIS profiles of the five biocatalysts analyzed are illustrated in figure 2 below.

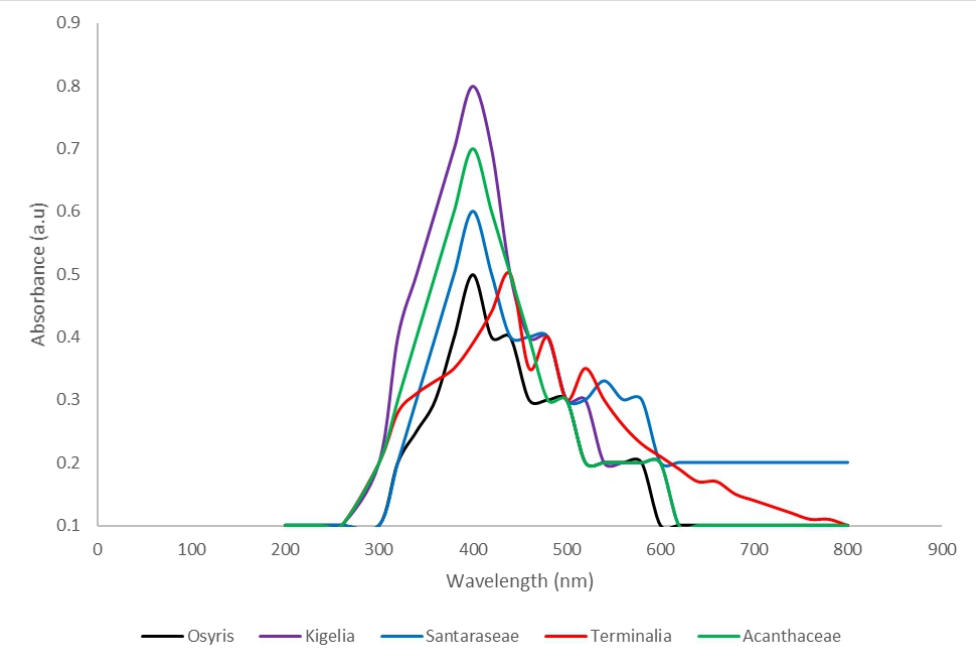

Figure 2; UV VIS spectra of the indigenous biocatalysts

All spectra except Terminalia $b$. sample had maximum absorption at 400nm. Niknejad et al. (2015); obtained similar spectra when analyzing yeast cells impregnated with silver nanoparticles. Similar findings were also reported by (Whitcombe et al. 2014) who obtained $\lambda_{\max }$ at $425 \mathrm{~nm}$ wavelength for yeast particles. Terminalia $b$. and Santaraseae spp. samples were found to have an absorption band at $460 \mathrm{~nm}$, citing presence of conjugated pigments such as carotenoids or xanthophylls, halo-alkanes and sulphate groups (Priyanka et al. 2015). These two biocatalysts also portrayed more peaks indicating more conjugation levels. Presence of halides in the Terminalia $b$. sample was confirmed by the peak at 540nm. A similar peak was present at 560nm in the Santaraseae spp. sample. Kigelia africana and Acanthaceae spp. samples exhibited stronger absorption peaks at 400nm but had fewer multiplicities.

\section{Bio-metal analysis of the biocatalysts}

Five bio-metals were analyzed for their concentrations in the biocatalytic extracts. Their presence is crucial in catalyzing biochemical reactions. Both iron and cobalt ions were found to be quite abundant in the test samples whereas chromium ions were the least concentrated. Table 3 below summarizes the concentrations of these bio-metals in $\mathrm{mg} / \mathrm{Kg}$ of wet plant sample. 
Table 3: Concentrations of bio-metals in the indigenous biocatalyst samples

\begin{tabular}{|c|c|c|c|c|c|}
\hline Sample & $\begin{array}{l}\text { Copper } \\
(\mathrm{mg} / \mathrm{Kg})\end{array}$ & Zinc (mg/Kg) & $\begin{array}{l}\text { Iron } \\
(\mathrm{mg} / \mathrm{Kg})\end{array}$ & Chromium(mg/Kg) & Cobalt (mg/Kg) \\
\hline $\begin{array}{l}\text { Terminalia } \\
b .\end{array}$ & $\begin{array}{l}72.020 \\
\pm 0.037\end{array}$ & $\begin{array}{l}69.285 \\
\pm 0.006\end{array}$ & $\begin{array}{l}242.645 \\
\pm 1.308\end{array}$ & $12.295 \pm 0.103$ & $\begin{array}{l}244.370 \\
\pm 0.303\end{array}$ \\
\hline $\begin{array}{l}\text { Acanthaceae } \\
\text { spp. }\end{array}$ & $75.855 \pm 0.202$ & $75.105 \pm 0.097$ & $\begin{array}{l}459.665 \\
\pm 0.827\end{array}$ & $24.595 \pm 0.154$ & $\begin{array}{l}487.755 \\
\pm 0.446\end{array}$ \\
\hline $\begin{array}{l}\text { Santaraseae } \\
\text { spp. }\end{array}$ & $102.620 \pm 1.229$ & $61.221 \pm 1.002$ & $\begin{array}{l}400.000 \pm \\
0.000\end{array}$ & $15.169 \pm 1.028$ & $403.600 \pm 12.108$ \\
\hline $\begin{array}{l}\text { Osyris } \\
\text { lanceolata }\end{array}$ & $106.752 \pm 3.457$ & $63.155 \pm 2.011$ & $\begin{array}{l}396.000 \pm \\
2.215\end{array}$ & $10.113 \pm 0.015$ & $403.321 \pm 1.240$ \\
\hline $\begin{array}{l}\text { Kigelia } \\
\text { africana }\end{array}$ & $97.155 \pm 6.120$ & $71.255 \pm 0.075$ & $\begin{array}{l}400.000 \pm \\
1.000\end{array}$ & $16.199 \pm 0.276$ & $401.440 \pm 2.500$ \\
\hline
\end{tabular}

Acanthaceae spp. was found to have the most abundant bio-metals except copper (most abundant in Osyris lanceolata). Only Santaraseae spp. and Osyris lanceolata had more than $100 \mathrm{mg} / \mathrm{Kg}$ of copper ions per wet sample. Vianello et al. (2014); reported that similar concentrations of copper ions deposited alongside histidine in laccase enzymes. Abundance of copper ions was attributed to enhanced enzymatic roles of ligninolytic enzymes (Kostadinova et al. 2018). The abundance of copper and zinc ions in plant samples is a function of several parameters including, the $\mathrm{pH}$, conductivity and levels of other compounds such as phosphates present (Chaka and Osano, 2019). The concentrations of these bio-metals are however largely affected by their immediate soil and water environment (Zhao et al. 2015). Together with zinc and manganese ions, copper ions have been used to enrich yeast (Saccharomyces cerevisae) in catalyzing degradation of biomass (Marjamaa and Kruus, 2018). Iron, zinc and cobalt in various concentrations have all been used as cofactors in biomass degradation enzymes (Haferburg and Kothe, 2007). The levels of chromium ions were all less than $25 \mathrm{mg} / \mathrm{Kg}$ of wet sample. Only Acanthaceae spp. had more than $20 \mathrm{mg} / \mathrm{Kg}(24.595 \pm 0.154 \mathrm{mg} / \mathrm{Kg})$ while Osyris lanceolata had as little as $10.113 \pm 0.015 \mathrm{mg} / \mathrm{Kg}$ of the wet sample. Stanley et al. (2014) reported that increased chromium (vi) concentration in enzymes lead to death of the enzymes. Chromium (vi) levels of higher than $4.0 \mathrm{mg} / \mathrm{Kg}$ of dry plant sample were proven to be toxic. The exact type of chromium ion and other bio-metal ions present are discussed under bio-metal speciation below. 


\section{Speciation of bio-metals present}

Different biochemical functions of enzymes and other biocatalysts are only achieved by metals at specific concentration ranges and ionic form. Elucidation of the exact form and abundance of bio-metal is detrimental in predicting the nature of reactions to be expected. Tables 4, 5, 6, 7 and 8 below summarize the speciation of these bio-metals when analyzed at their specific $\mathrm{pH}$, electrical conductivity and temperature. Only the most abundant ions species were recorded. Most of the species were found to be oxides and hydroxides.

\section{Copper}

Table 4 below summarizes the speciation of copper ions in the five indigenous biocatalysts analyzed.

Table 4: Speciation of copper ions in the biocatalysts

\begin{tabular}{lllll}
\hline Sample & $\mathbf{C u}^{+}$ & $\mathbf{C u}(\mathbf{O H})_{2}$ & $\mathbf{C u O H}^{+}$ & $\mathbf{C u}_{2}(\mathbf{O H})_{2}$ \\
\hline Terminalia b. $(\%)$ & 1.573 & 95.283 & 3.069 & 0.075 \\
Acanthaceae spp. $(\%)$ & 1.560 & 94.617 & 3.043 & 0.078 \\
Santaraseae spp. $(\%)$ & 2.653 & 55.852 & 4.032 & 37.464 \\
Osyris lanceolata $(\%)$ & 11.836 & 1.571 & 1.836 & 84.757 \\
Kigelia africana $(\%)$ & 1.749 & 76.959 & 2.291 & 18.127 \\
\hline
\end{tabular}

From table 4 above, $\mathrm{Cu}(\mathrm{OH})_{2}$ was the prevalent ion in all biocatalysts except in Osyris lanceolata sample. Osyris lanceolata had an extremely low $\mathrm{pH}$ value $(5.950 \pm 1.001)$ and conductivity $(31.200 \pm 2.436 \mathrm{mS})$ which might have contributed to this variance. Santaraseae spp. sample which also had low pH and conductivity had less $\mathrm{Cu}(\mathrm{OH})_{2}$ ions. Copper (ii) ions have been found in various oxidase and reductase enzymes (Gromov et al. 1999) in plant samples. Copper (ii) hydroxide ions in ammonia solution form Schweizer's reagent which have been proven to dissolve cellulose (Tomczyńska-Mleko et al. 2015). Natural occurrence of these ions in the bio-catalysts position them as potential cellulose degrading extracts. Only Osyris lanceolata had more than $10 \%$ of copper (i) ions present.

\section{Iron}

Iron and cobalt were found to be abundant in all the bio-metals analyzed. Several hydroxides of iron were recorded as being the most abundant. These findings were recorded in table 5 below. 
Table 5: Speciation of the most abundant iron species in the biocatalysts

\begin{tabular}{llllll}
\hline Sample & $\mathbf{F e O H}^{+}$ & $\mathbf{F e}(\mathbf{O H})_{3}$ & $\mathbf{F e}(\mathbf{O H})^{2+}$ & $\mathbf{F e}(\mathbf{O H})^{-}$ & $\mathbf{F e O H}^{+2}$ \\
\hline Terminalia b. (\%) & 77.830 & 11.739 & 10.329 & 0.098 & 0.004 \\
Acanthaceae spp. (\%) & 78.139 & 11.549 & 10.213 & 0.097 & 0.004 \\
Santaraseae spp. (\%) & 1.950 & 38.709 & 59.060 & 0.237 & 0.044 \\
Osyris lanceolata (\%) & 21.982 & 3.167 & 73.575 & 0.004 & 1.272 \\
Kigelia africana (\%) & 2.741 & 33.387 & 63.648 & 0.165 & 0.050 \\
\hline
\end{tabular}

Hydroxides of ferric $\left(\mathrm{Fe}(\mathrm{OH})^{2+}\right)$ ions were prevalent in Santaraseae spp., Osyris lanceolata and Kigelia africana while ferrous hydroxides $\left(\mathrm{FeOH}^{+}\right)$ dominated in Terminalia $b$. and Acanthaceae spp. extracts. Both ferric and ferrous ions in plants have been reported to catalyze movement of electrons in plants during biochemical reactions (Lindh, 2007). Such movements in biocatalytic plants increase the rate of fermentation of cellulose. Ferric ions have been reported to be abundant in citric and oxalic acids, all used during fermentation process (Barbeau, 2006). Kimata et al. (2018); found out that ferric ions in bio-metals participate in redox biochemical reactions. Ferric ions have also been reported as key factors for the growth of yeast (a biocatalyst) (Sreenivasan et al., 1993). Ranawat and Rawat, (2018); also reported ferric ions to be crucial electron acceptors in anaerobic respiration process.

\section{Zinc}

There are over 300 zinc enzymes covering all the six classes of enzymes (Garingrdestedt et al. 2009). Elucidation of the exact specie of zinc ions in the biocatalysts was summarized in table 6 below.

Table 6: Speciation of zinc ions in biocatalysts

\begin{tabular}{lll}
\hline Sample & $\mathbf{Z n O H}^{+}$ & $\mathbf{Z n}(\mathbf{O H})_{2}$ \\
\hline Terminalia b. (\%) & 99.882 & 0.1172 \\
Acanthaceae spp. (\%) & 99.880 & 0.115 \\
Santaraseae spp. (\%) & 89.107 & 10.893 \\
Osyris lanceolata (\%) & 98.957 & 1.043 \\
Kigelia africana $(\%)$ & 89.673 & 10.327 \\
\hline
\end{tabular}

All the zinc ions were found to be divalent in the biocatalytic samples. Several researchers have found out that zinc is not readily oxidized or reduced from its +2-oxidation state (Ahmad et al. 2012). From table 6 above, most of the biocatalysts zinc ions were $\mathrm{ZnOH}^{+}$for all the test samples. This implied that 
zinc (ii) ions with one hydroxide group and a vacant coordination site were prevalent in the biocatalysts at slightly acidic $\mathrm{pH}$ and low temperatures (about 17-19 ${ }^{\circ} \mathrm{C}$ ). Krezel and Maret (2016); McCall et al. (2000); showed that according to Pourbaix diagram, in the absence of other coordinating ligands, zinc ions are only present in biological compounds as zinc (ii) ions. Zinc is thus redox-inert in biocatalysts and all other biological compounds. Zastrow and Pecoraro, (2014); proved that hydrolytic zinc (ii) ions were the dominant ions in hydrase enzymes.

\section{Chromium}

Chromium toxicity has previously been cited as one of the factors leading to death of enzymes (Stanley et al. 2014). This phenomenon is caused by chromium (vi) ions. On the other hand, chromium (iii) ions are important catalysts with the ability to hasten organic and inorganic processes (Soheili et al. 2018). The variations of chromium ions in the biocatalyst samples analyzed are summarized in table 7 below. Most of the species were found to have hydroxide ligands.

Table 7: Speciation of chromium ions in biocatalyst extracts

\begin{tabular}{llllllll}
\hline Sample & $\mathbf{C r}(\mathbf{O H})^{2+}$ & $\mathbf{C r}(\mathbf{O H})_{3}$ & $\mathbf{C r}(\mathbf{O H})_{2}{ }^{+}$ & $\mathbf{C r}^{+3}$ & $\mathbf{C r}_{3}(\mathbf{O H})_{4}{ }^{+}$ & $\mathbf{C r}_{2}(\mathbf{O H})_{2}{ }^{+}$ & $\mathbf{C r}(\mathbf{O H})_{4}^{-}$ \\
\hline Terminalia b. (\%) & 73.140 & 17.114 & 9.701 & 0.044 & 0.001 & 0.000 & 0.001 \\
Acanthaceae spp. (\%) & 73.132 & 17.102 & 9.720 & 0.044 & 0.001 & 0.000 & 0.001 \\
Santaraseae spp. (\%) & 63.509 & 2.157 & 5.859 & 0.012 & 28.397 & 0.058 & 0.007 \\
Osyris lanceolata (\%) & 0.271 & 0.001 & 0.582 & 0.000 & 98.965 & 0.181 & 0.000 \\
Kigelia africana (\%) & 58.850 & 1.698 & 6.414 & 0.015 & 32.948 & 0.071 & 0.005 \\
\hline
\end{tabular}

All biocatalysts had chromium (iii) ions with one hydroxide ligand as the dominant specie except Osyris lanceolata extracts. The prevalent specie in Osyris lanceolata was $\mathrm{Cr}_{3}(\mathrm{OH})_{4}{ }^{+}$. These species were also quite abundant in Santaraseae spp. and Kigelia africana extracts. Oliviera (2012) reported abundance of trivalent chromium in enzymes used in sugar metabolism. The ions also play key roles in sugar tolerance levels in animals (Hua et al. 2012). Other trivalent chromium ions with hydroxide groups accounted for up to $20 \%$ in the biocatalyst extracts. Terminalia $b$. and Acanthaceae spp. samples were the most diverse as far as the abundance of chromium ions were concerned; lacking only $\mathrm{Cr}_{2}(\mathrm{OH})_{2}{ }^{+}$present in the other biocatalysts.

\section{Cobalt}

Cobalt has the ability to complex with several enzymes, acting as a cofactor in their processes (Remy et al. 2013). Determination of the exact ions and possible number of coordination sites in the cobalt complexes is 
fundamental in modelling industrial biocatalysts for fermentation process. The speciation of the abundant cobalt ions in the biocatalysts were summarized in table 8 below.

Table 8: Speciation of cobalt ions in biocatalytic extracts

\begin{tabular}{lllll}
\hline Sample & $\mathbf{H C o O}_{2}^{-}$ & $\mathbf{C o}(\mathbf{O H})_{2}$ & $\mathbf{C o}^{2+}$ & $\mathbf{C o}_{2} \mathbf{O H}^{+3}$ \\
\hline Terminalia b. $(\%)$ & 5.581 & 0.000 & 94.419 & 0.000 \\
Acanthaceae spp. $(\%)$ & 56.549 & 0.001 & 43.451 & 0.000 \\
Santaraseae spp. $(\%)$ & 99.997 & 0.003 & 0.000 & 0.000 \\
Osyris lanceolata $(\%)$ & 0.014 & 0.000 & 99.985 & 0.001 \\
Kigelia africana $(\%)$ & 10.058 & 0.000 & 89.942 & 0.000 \\
\hline
\end{tabular}

The abundance of cobalt ions in the biocatalysts varied between hydroxy (oxo) cobalt ions $\left(\mathrm{HCoO}_{2}^{-}\right)$and 'other' cobalt (ii) ions $\left(\mathrm{Co}^{2+}\right)$. The Acanthaceae spp. extracts were quite diverse in the two ions, with both having almost equal distribution. Hoppert (2011) reported abundance of cobalt (ii) ions in non-corrin enzymes involved in catalyzing the oxidation of nitriles to amides (nitrile hydratase enzymes). Cobalt (ii) ions were also found to supersede their cobalt (iii) counterparts in speciation studies conducted on methanogenic cells (Paulo et al. 2017). The research however found out that the cobalt (ii) ions favored chloride, carbonates and citrate ligands unlike the oxide ligand in Acanthaceae spp. and Santaraseae spp. above.

\section{Analysis of ligands present Nitrates}

Nitrate concentration in anaerobic digestion substrate is seen as an inhibitor of the whole fermentation process (Świątczak, and CydzikKwiatkowska, 2018). Anaerobic digestion process is proportional to Chemical Oxygen Demand (COD)/Nitrogen ratio. Over anaerobic digestion retention period, nitrates present in the substrate are gradually reduced to nitrites and nitriles (Igamberdiev and Hill, 2004). Viewing the scenario from a biocatalytic angle (nitrates present in the biocatalysts) is however quite complicated. Dyckmans et al. (2006); found the growth of anaerobic archea to be affected by presence of nitrates. The fermentation patterns for lactate, glycerol and pyruvate compounds were also inhibited in nitrate media (Patil et al., 2017). Figure 3 below illustrates the UV VIS profiles of the five biocatalysts $\left(\lambda_{\max }=\right.$ $550 \mathrm{~nm})$. 


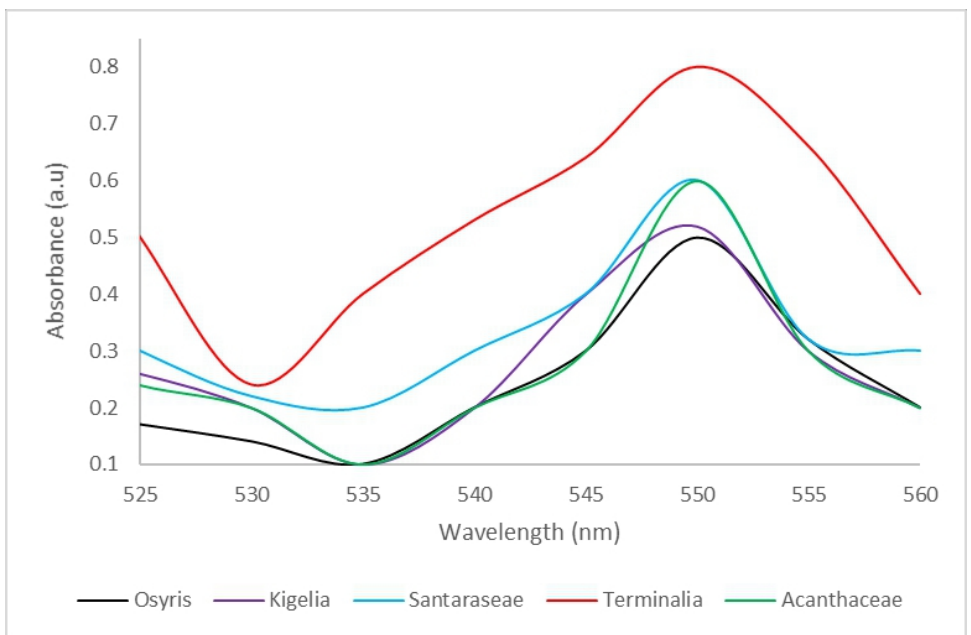

Figure 3; UV VIS spectra of the biocatalyst nitrates $\left(\lambda_{\max }=550 \mathrm{~nm}\right)$

The levels of nitrate ions were most abundant in Terminalia $b$. samples. Nitrate levels in this biocatalyst was significantly higher and different from the other extracts. Abundance of nitrates in amylase enzymes was found to increase the activity of the enzymes in solid state fermentation of soluble starch (Sethi et al. 2016). Increased nitrate and chloride ions concentrations in the enzymes yielded significantly higher products compared to the control.

\section{Sulfates}

Alongside ferric ions $\left(\mathrm{Fe}^{3+}\right)$ and nitrates, sulfate ions are fundamental inorganic compounds used as electron acceptors in anaerobic respiration process (Aharon, 2011). Another organic compound with sulfate ions and responsible for altering anaerobic digestion is dimethyl sulfoxide (DMSO) reagent (Ali et al. 2014). The levels of sulfate ions in the extracts of the biocatalysts were screened at $\lambda_{\max }=425 \mathrm{~nm}$ using UV VIS. From the UV VIS spectra, there was a lot of disparity in the levels of sulfates. Figure 4 below illustrates the spectra of sulfates in the biocatalyst samples. 


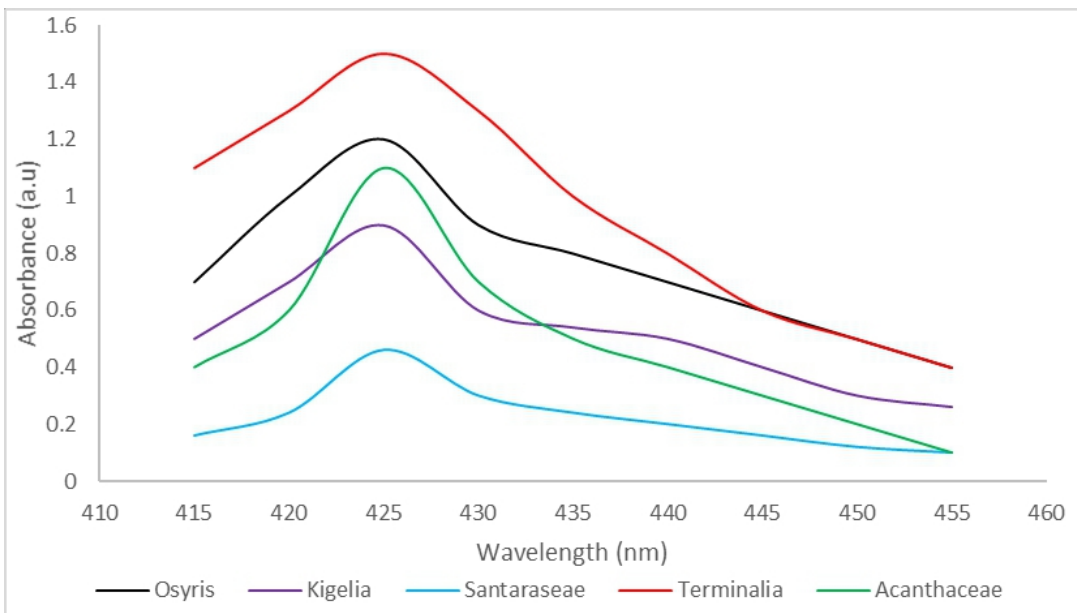

Figure 4; UV VIS spectra showing the sulfate levels in the biocatalysts $\left(\lambda_{\max }=425 \mathrm{~nm}\right)$

Sulfate levels in the biocatalyst extracts were in the order of Terminalia b., Osyris lanceolata, Acanthaceae spp., Kigelia africana and Santaraseae spp. The results imply that Terminalia $b$. would be most suitable in electron transfer effectively degrading more glucose molecules in lactate and pyruvate fermentation processes. In such reactions, more sulphide products are likely to be formed due to the reduction processes. Ali et al. (2014) also reports $\delta$-proteobacteria used in biomass hydrolysis being more efficient as sulfate levels increased.

\section{Phosphates}

Phosphate ions are involved in phosphylation process during breakdown of glucose to produce energy by respiration (Lodish et al. 2000). These ions can also be used in fermentation process (anaerobic). From the spectra, Santaraseae spp. extracts showed the highest levels of phosphates followed by Terminalia b., Osyris lanceolata, Acanthaceae spp. and Kigelia africana. Hara et al. (2015); reported phosphate levels as being key in catalysis of glyceraldehydes in biomass. Presence of phosphates in pyro-phosphate releasing enzymes was found to trigger rapid degradation of inosines (Suarez et al. 2012). The levels of phosphate ions in the biocatalyst samples were analyzed by UV VIS spectroscopy as illustrated in figure 5 below. 


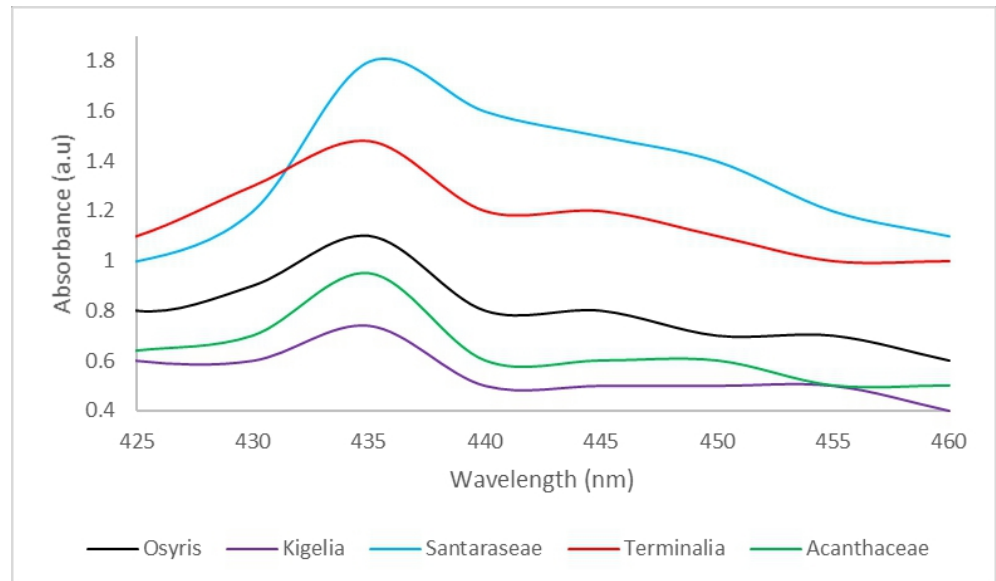

Figure 5; The UV VIS spectra of phosphates in the biocatalyst samples $\left(\lambda_{\max }=435 \mathrm{~nm}\right)$

From figure 5 above, Santaraseae spp. and Terminalia $b$. samples would be more suitable in phosphylation enzymatic processes compared to the other biocatalysts. Increased phosphate levels in enzymes were found to accelerate the functioning of adenosine triphosphate synthase molecule, effectively increasing the energy products obtained (Meyrat, 2019).

\section{Conclusion}

The study found out several similarities in physical chemical parameters, composition and ionic stability of the biocatalytic extracts analyzed. The $\mathrm{pH}$, conductivity and solid content of the biocatalysts were similar except for Osyris lanceolata which had relatively lower values. Acanthaceae spp. extracts had lower oxygen concentrations compared to the other samples. Only Santaraseae spp. extracts had more than $35 \mathrm{mg} / \mathrm{L}$ of volatile fatty acids. All the other biocatalysts had volatile acids in the range of 29-32 mg/L. Similar FT-IR patterns were observed in the spectra of all the biocatalysts. All samples had characteristic peaks at $2250 \mathrm{~cm}^{-1}, 2850 \mathrm{~cm}^{-1}$ and two close peaks at around $1500 \mathrm{~cm}^{-1}$.

Analogous UV VIS spectra were also observed with a broad peak around $400 \mathrm{~nm}$ wavelength. Terminalia $b$. and Osyris lanceolata extracts showed more multiplicities in the spectra citing more conjugation. The biocatalysts recorded high level uniformity in bio-metal concentration and speciation. Acanthaceae spp. extracts were found to have the most bio-metal abundance while Terminalia $b$. samples had the least. The ions of $\mathrm{Cu}(\mathrm{OH})_{2}$, $\mathrm{Fe}(\mathrm{OH})^{2+}, \mathrm{ZnOH}^{+}, \mathrm{Cr}(\mathrm{OH})^{2+}$ and $\mathrm{Co}^{2+}$ were found to be dominant in all biocatalyst extracts. Terminalia $b$. and Osyris lanceolata were found to have relatively higher sulfate, phosphate levels while nitrate levels were similar in all the samples except for Terminalia $b$. biocatalysts. 


\section{Acknowledgement}

The authors wish to express their sincere gratitude to Maasai mara university chemistry lab and Centre for Innovation, New and Renewable Energy (CINRE) personnel for provision of facilities and labor to prepare and characterize the biocatalysts. Multimedia university also aided in UV VIS analysis of the biocatalysts. Special thanks to Patrick Lumumba, Rutto Kenneth and Linda Mesoppirr for their assistance in analysis.

\section{Referances:}

1. Aharon O., (2011). Diversity of Anaerobic Prokaryotes and Eukaryotes: Breaking Long-Established Dogmas, Anoxia, 8, 3, 39-47.

2. Ahmad, M., Ahmed, E., Khalid, N. R., Jackson, M. J., \& Ahmed, W. J. (2012). Synthesis and Characterization of Hexagonal Shaped Nanocrystalline Zinc Oxide Powders. International Journal of Manufacturing, Materials, and Mechanical Engineering (ijmmme), 2, 2, 61-76.

3. Ali S, F., Mahmood, Q., Maroof S. M., Pervez, A., \& Ahmad Asad, S. (2014). Microbial ecology of anaerobic digesters: the key players of anaerobiosis. The Scientific World Journal, 2014, 183752.

4. Amend, J. P., \& Shock, E. L. (2001). Energetics of overall metabolic reactions of thermophilic and hyperthermophilic Archaea and Bacteria. Fems Microbiology Reviews, 25, 2, 175-243.

5. Barbeau, K. (2006). Photochemistry of Organic Iron (III) Complexing Ligands in Oceanic Systems. Photochemistry and Photobiology, 82, 6, 1505-1516.

6. Behenna, D. C., Mohr, J. T., Sherden, N. H., Marinescu, S. C., Harned, A. M., Tani, K., Seto, M., ... Stoltz, B. M. (2011). Enantioselective Decarboxylative Alkylation Reactions: Catalyst Development, Substrate Scope, and Mechanistic Studies. Chemistry - a European Journal, 17, 50, 14199-14223.

7. Berthelot, V., Albarello, H., \& Broudiscou, L. P. (2019). Effect of extruded linseed supplementation, grain source and $\mathrm{pH}$ on dietary and microbial fatty acid outflows in continuous cultures of rumen microorganisms. Animal Feed Science and Technology, 249, 76-87.

8. Bychkov, A. L., Ryabchikova, E. I., Korolev, K. G., Lomovskaya, T. F., \& Lomovskii, O. I. (2016). Mechanically activated enzymatic hydrolysis of yeast biomass. Catalysis in Industry, 8, 4, 354-360.

9. Chaka B. and Osano A. (2019). Analysis of selected nutrient levels at different growth stages of Dovyalis caffra (kei-apple fruits). Intl. Journal of Research and Innovation in Applied Sciences. Vol 4(5).1118. 
10. Chude-Okonkwo, U. A. K., Malekian, R., Maharaj, B. T., \& Vasilakos, A. V. (2017). Molecular Communication and Nanonetwork for Targeted Drug Delivery: A Survey. Ieee Communications Surveys \&amp; Tutorials, 19, 4, 3046-3096.

11. Don, A., Osborne, B., Hastings, A., Skiba, U., Carter, M. S., Drewer, J., Flessa, H., ... Zenone, T. (2012). Land-use change to bioenergy production in Europe: implications for the greenhouse gas balance and soil carbon. Gcb Bioenergy, 4, 4, 372-391.

12. Duijnhoven, S. M. J., Robillard, M. S., Langereis, S., \& Grüll, H. (2015). Bioresponsive probes for molecular imaging: concepts and in vivo applications. Contrast Media \& Molecular Imaging, 10, 4, 282308.

13. Dyckmans, J., Flessa, H., Lipski, A., Potthoff, M., \& Beese, F. (2006). Microbial biomass and activity under oxic and anoxic conditions as affected by nitrate additions. Journal of Plant Nutrition and Soil Science, 169, 1, 108-115.

14. Garingrdestedt, C., Plea, M., Nilsson, G., Jacks, B., \& Jacks, G. (2009). Zinc in Soils, Crops, and Meals in the Niger Inland Delta, Mali. Ambio: A Journal of the Human Environment, 38, 6, 334-338.

15. Goacher, R. E., Braham, E. J., Michienzi, C. L., Flick, R. M., Yakunin, A. F., \& Master, E. R. (2018). Direct analysis by time-of-flight secondary ion mass spectrometry reveals action of bacterial laccasemediator systems on both hardwood and softwood samples. Physiologia Plantarum, 164, 1, 5-16.

16. Gromov, I., Marchesini, A., Farver, O., Pecht, I., \& Goldfarb, D. (1999). Azide binding to the trinuclear copper center in laccase and ascorbate oxidase. European Journal of Biochemistry, 266, 3, 820830.

17. Haferburg, G., \& Kothe, E. (2007). Microbes and metals: interactions in the environment. Journal of Basic Microbiology, 47, 6, 453-467.

18. Hara, M., Nakajima, K., \& Kamata, K. (2015). Recent progress in the development of solid catalysts for biomass conversion into high valueadded chemicals. Science and technology of advanced materials, 16(3), 034903.

19. Harvey, D. J. (, 2015). Analysis of carbohydrates and glycoconjugates by matrix-assisted laser desorption/ionization mass spectrometry: An update for 2009-2010. Mass Spectrometry Reviews, 34, 3, 268-422.

20. Hasan, H. A., Abdulmalek, E., Rahman, M. B. A., Shaari, K. B., Yamin, B. M., \& Chan, K. W. (2018). Microwave synthesis, crystal structure, antioxidant, and antimicrobial study of new 6-heptyl-5,6dihydrobenzo [4,5]imidazo[1,2- quinazoline compound. Chemistry Central Journal, 12, 1, 1-15. 
21. Hoppert M. (2011) Metalloenzymes. In: Reitner J., Thiel V. (eds) Encyclopedia of Geobiology. Encyclopedia of Earth Sciences Series. Springer, Dordrecht. 1-28.

22. Hua, Y., Clark, S., Ren, J., \& Sreejayan, N. (2012). Molecular mechanisms of chromium in alleviating insulin resistance. The Journal of nutritional biochemistry, 23(4), 313-319. doi:10.1016/j.jnutbio.2011.11.001

23. Igamberdiev, A. U., \& Hill, R. D. (2004). Nitrate, NO and haemoglobin in plant adaptation to hypoxia: an alternative to classic fermentation pathways. Journal of Experimental Botany, 55, 408, 2473-2482.

24. Jakubowska, M., \& Normant-Saremba, M. (2015). The Effect of COInduced Seawater Acidification on the Behaviour and Metabolic Rate of the Baltic Clam Macoma balthica. Annales Zoologici Fennici, 52, 353-367.

25. Kaldor, A., \& Woodin, R. L. (1982). Applications of lasers to chemical processing. Proceedings of the Ieee, 70, 6, 565-578.

26. Kalyani, D., Fakin, T., Horn, S. J., \& Tschentscher, R. (2017). Valorisation of woody biomass by combining enzymatic saccharification and pyrolysis. Green Chemistry, 19, 3302-3312.

27. Kimata, S., Mochizuki, D., Satoh, J., Kitano, K., Kanesaki, Y., Takeda, K., Abe, A., ... Niimura, Y. (2018). Intracellular free flavin and its associated enzymes participate in oxygen and iron metabolism in Amphibacillus xylanus lacking a respiratory chain. Febs Open Bio, 8, 6, 947-961.

28. Kostadinova, N., Krumova, E., Boeva, R., Abrashev, R., MitevaStaleva, J., Spassova, B., \& Angelova, M. (2018). Effect of copper ions on the ligninolytic enzyme complex and the antioxidant enzyme activity in the white-rot fungus Trametes trogii 46. Plant Biosystems an International Journal Dealing with All Aspects of Plant Biology, 152, 5, 1128-1133.

29. Krężel, A., \& Maret, W. (2016). The biological inorganic chemistry of zinc ions. Archives of biochemistry and biophysics, 611, 3-19.

30. Kristoffersen, K. A., Liland, K. H., Böcker, U., Wubshet, S. G., Lindberg, D., Horn, S. J., \& Afseth, N. K. (2019). FTIR-based hierarchical modeling for prediction of average molecular weights of protein hydrolysates. Talanta, 205, 120084.

31. Kuzyakov, Y., \& Xu, X. (2013). Competition between roots and microorganisms for nitrogen: mechanisms and ecological relevance. New Phytologist, 198, 3, 656-669.

32. Li, S., Bashline, L., Lei, L., \& Gu, Y. (2014). Cellulose Synthesis and Its Regulation. The Arabidopsis Book.12 
33. Lillebø, A. H., Holmen, A., Enger, B. C., \& Blekkan, E. A. (2013). Fischer-Tropsch conversion of biomass-derived synthesis gas to liquid fuels. Wiley Interdisciplinary Reviews: Energy and Environment, 2, 5, 507-524

34. Lin, C. S. K., Koutinas, A. A., Stamatelatou, K., Mubofu, E. B., Matharu, A. S., Kopsahelis, N., Pfaltzgraff, L. A., ... Luque, R. (2014). Current and future trends in food waste valorization for the production of chemicals, materials and fuels: a global perspective. Biofuels, Bioproducts and Biorefining, 8, 5, 686-715.

35. Lindh, U. (2007). Metal Biology: Aspects of Beneficial Effects. Ambio: A Journal of the Human Environment, 36, 1, 107-110.

36. Lodish H, Berk A, (2000). Zipursky SL, et al. Molecular Cell Biology. 4th edition. New York: W. H. Freeman; 2000. Section 16.1, Oxidation of Glucose and Fatty Acids to $\mathrm{CO} 2$. Available from: https://www.ncbi.nlm.nih.gov/books/NBK21624/

37. Mandenius, C.-F., \& Gustavsson, R. (2015). Mini-review: soft sensors as means for PAT in the manufacture of bio-therapeutics. Journal of Chemical Technology \& Biotechnology, 90, 2, 215-227.

38. Marjamaa, K., \& Kruus, K. (2018). Enzyme biotechnology in degradation and modification of plant cell wall polymers. Physiologia Plantarum, 164, 1, 106-118.

39. Marriott, P. E., Gómez, L. D., \& McQueen-Mason, S. J. (2016). Unlocking the potential of lignocellulosic biomass through plant science. New Phytologist, 209, 4, 1366-1381.

40. Marzialetti, T., Miller, S. J., Jones, C. W., \& Agrawal, P. K. (2011). Switchgrass pretreatment and hydrolysis using low concentrations of formic acid. Journal of Chemical Technology \& Biotechnology, 86, 5, 706-713.

41. McCall, K., Chih-chin H., Carol A. F., (2000) Function and Mechanism of Zinc Metalloenzymes, The Journal of Nutrition, Volume 130, Issue 5, Pages 1437-1446

42. Meyrat, C. (2019). ATP synthesis at physiological nucleotide concentrations, Scientific Reports Journal. 9(1). 2045-2322.

43. Mihoubi, W., Sahli, E., Gargouri, A., \& Amiel, C. (2017). FTIR spectroscopy of whole cells for the monitoring of yeast apoptosis mediated by 533 over-expression and its suppression by Nigella sativa extracts. Plos One, 12, 7.)

44. Minarrieta, L., Ghorbani, P., Sparwasser, T., \& Berod, L. (2017). Metabolites: deciphering the molecular language between DCs and their environment. Seminars in Immunopathology, 39, 2, 177-198.

45. Niknejad, F., Nabili, M., Daie, G. R., \& Moazeni, M. (2015). Green synthesis of silver nanoparticles: Advantages of the yeast 
Saccharomyces cerevisiae model. Current Medical Mycology, 1, 3, $17-24$.

46. Oliveira, H., (2012). "Chromium as an Environmental Pollutant: Insights on Induced Plant Toxicity," Journal of Botany, vol. 2012, Article ID 375843, 8 pages,

47. Osano A., Okong'o E., Oyaro N. and Kiptoo J. (2015). A Study of the Heterogeneous Dilute Indigenous Carbonate Salt Hydrolysis of the Non-Woody Ligno-Cellulosic Plant Samples. International Journal of Scientific \& Engineering Research, Volume 4, Issue 6, June-2013. 333.

48. Ouyang, J., Cai, C., Chen, H., Jiang, T., \& Zheng, Z. (2012). Efficient non-sterilized fermentation of biomass-derived xylose to lactic acid by a thermotolerant Bacillus coagulans NL01. Applied Biochemistry and Biotechnology, 168, 8, 2387-97.

49. Panagiotopoulou, P., Papadopoulou, C., Matralis, H., \& Verykios, X. (2014). Production of renewable hydrogen by reformation of biofuels. Wiley Interdisciplinary Reviews: Energy and Environment, 3, 3, 231-253.

50. Patil, Y., Junghare, M., \& Müller, N. (2017). Fermentation of glycerol by Anaerobium acetethylicum and its potential use in biofuel production. Microbial biotechnology, 10(1), 203-217.

51. Paulo L. M., Ramiro-Garcia J. S., Stams A. J. M., Sousa D. Z., (2017). Effect of Nickel and Cobalt on Methanogenic Enrichment Cultures and Role of Biogenic Sulfide in Metal Toxicity Attenuation. Journal of Frontiers in Microbiology, Vol. 8. Pg 1341.

52. Priyanka, S., Yeon, J. K., Hina, S., Ramya, M., Chao, W., \& Deok, C. Y. (2015). Biosynthesis of Anisotropic Silver Nanoparticles by Bhargavaea indica and Their Synergistic Effect with Antibiotics against Pathogenic Microorganisms. Journal of Nanomaterials, 2015.10

53. Ranawat, P., \& Rawat, S. (2018). Metal-tolerant thermophiles: metals as electron donors and acceptors, toxicity, tolerance and industrial applications. Environmental Science and Pollution Research, 25, 5, 4105-4133.

54. Remy, L., Carrière, M., Derré-Bobillot, A., Martini, C., Sanguinetti, M., \& Borezée-Durant, E. (2013). The Staphylococcus aureus Opp1 $\mathrm{ABC}$ transporter imports nickel and cobalt in zinc-depleted conditions and contributes to virulence. Molecular Microbiology, 87, 4, 730-43.

55. Schultz, C., Powell, K., Crossley, A., Jurkschat, K., Kille, P., Morgan, A. J., Read, D., ... Spurgeon, D. J. (2015). Analytical approaches to support current understanding of exposure, uptake and distributions of 
engineered nanoparticles by aquatic and terrestrial organisms. Ecotoxicology, 24, 2, 239-261.

56. Sethi, B. K., Jana, A., Nanda, P. K., DasMohapatra, P. K., Sahoo, S. L., \& Patra, J. K. (2016). Production of $\alpha$-Amylase by Aspergillus terreus NCFT 4269.10 Using Pearl Millet and Its Structural Characterization. Frontiers in plant science, 7, 639.

57. Soheili, M., Mohamadnia, Z., \& Karimi, B. (2018). Switching from Ethylene Trimerization to Ethylene Polymerization by Chromium Catalysts Bearing SNS Tridentate Ligands: Process Optimization Using Response Surface Methodology. Catalysis Letters, 148, 12, 3685-3700.

58. Soria, G., Merino, G., Uribe, E., \& Brand, E. (2011). Effect of Increasing Salinity on Weight-Specific Filtration Rate of Juvenile Scallop Argopecten purpuratus Reared at Two Temperatures: Is Any Effect Related to Ammonia Buildup? Journal of Shellfish Research, 30, 2, 279-286.

59. Sparks, D. L. (2015). Advances in coupling of kinetics and molecular scale tools to shed light on soil biogeochemical processes. Plant and Soil: An International Journal on Plant-Soil Relationships, 387, 1-19.

60. Sreenivasan, P. K., Meyer, D. H., \& Fives-Taylor, P. M. (1993). Factors influencing the growth and viability of Actinobacillus actinomycetemcomitans. Oral Microbiology and Immunology, 8, 6, 361-369.

61. Sridevi, A., Narasimha, G., Ramanjaneyulu, G., Dileepkumar, K., Reddy, B. R., \& Devi, P. S. (2015). Saccharification of pretreated sawdust by Aspergillus niger cellulase. 3 Biotech, 5, 6, 883-892.

62. Stanley, J. A., Sivakumar, K. K., Arosh, J. A., Burghardt, R. C., \& Banu, S. K. (2014). Edaravone Mitigates Hexavalent ChromiumInduced Oxidative Stress and Depletion of Antioxidant Enzymes while Estrogen Restores Antioxidant Enzymes in the Rat Ovary in F1 Offspring 1. Biology of Reproduction, 91, 1.)

63. Stöckmann, C., Palmen, T. G., Schroer, K., Kunze, G., Gellissen, G., \& Büchs, J. (2014). Definition of culture conditions for Arxula adeninivorans, a rational basis for studying heterologous gene expression in this dimorphic yeast. Journal of Industrial Microbiology \& Biotechnology: Official Journal of the Society for Industrial Microbiology and Biotechnology, 41, 6, 965-976.

64. Suárez A. S., Stefan A, Lemma S, Conte E, Hochkoeppler A. (2012). Continuous enzyme-coupled assay of phosphate- or pyrophosphatereleasing enzymes. Biotechniques. 53(2):99-103.

65. Świątczak, P., \& Cydzik-Kwiatkowska, A. (2018). Treatment of Ammonium-Rich Digestate from Methane Fermentation Using 
Aerobic Granular Sludge. Water, Air, \& Soil Pollution: An International Journal of Environmental Pollution, 229, 8, 1-12.

66. Tomczyńska-Mleko, M., Terpiłowski, K., \& Mleko, S. (2015). New product development: Cellulose/egg white protein blend fibers. Carbohydrate Polymers, 126, 168-74.

67. Vianello, F., Miotto, G., Cambria, M. T., Lima, G. P. P., Vanzani, P., \& Di, P. M. L. (2014). Kinetic role of a histidine residue in the T1 copper site of the laccase fromRigidoporus lignosus. Journal of Molecular Catalysis. B, Enzymatic, 99, 34-42.

68. Whitcombe, M. J., Kirsch, N., \& Nicholls, I. A. (2014). Molecular imprinting science and technology: a survey of the literature for the years 2004-2011. Journal of Molecular Recognition, 27, 6, 297-401.

69. Wright, J., \& Solar Energy Research Institute, Golden, CO (US). (1988). Ethanol from biomass by enzymatic hydrolysis. Chem. Eng. Prog, 62-74.

70. Yao, J., Liu, J., Zhang, Y., Xu, S., Hong, Y., \& Chen, Y. (2019). Adding an anaerobic step can rapidly inhibit sludge bulking in SBR reactor. Scientific Reports, 9, 1, 1-10.

71. Yuki, M., Moriya, S., Inoue, T., \& Kudo, T. (2008). Transcriptome Analysis of the Digestive Organs of Hodotermopsis sjostedti, a Lower Termite That Hosts Mutualistic Microorganisms in Its Hindgut. Zoological Science, 25, 4, 401-406.

72. Zastrow, M. L., \& Pecoraro, V. L. (2014). Designing hydrolytic zinc metalloenzymes. Biochemistry, 53(6), 957-978.

73. Zhao, W., Ding, L., Gu, X., Luo, J., Liu, Y., Guo, L., Shi, Y., ... Cheng, S. (2015). Levels and ecological risk assessment of metals in soils from a typical e-waste recycling region in southeast China. Ecotoxicology, 24, 9, 1947-1960. 